\title{
Pineapples Extract as Replacement of Povidon Ioudium in Incision Wound Healing
}

\author{
Syamsul Arif ${ }^{1}$, Joni Siwanto ${ }^{2}$, Putrono ${ }^{3}$ \\ ${ }^{1,2,3}$ Poltekkes Kemenkes Semarang. Jln. Tirto Agung Pedalangan, Banyumanik, Semarang 50239, Indonesia
}

*Corresponding Author: Syamsul Arif, Poltekkes Kemenkes Semarang. Jln. Tirto Agung Pedalangan, Banyumanik, Semarang 50239, Indonesia .Email: Cepungmarupung@gmail.com

\begin{abstract}
:
Background: Skin damage to the wound can reduce the ability of the body's defense system. Wound care is essential to accelerate the healing process. It is necessary to consider the use of traditional medicinal plants in the treatment of wounds to speed up wound healing and safe for the body.
\end{abstract}

The Objective: The objective of the study was to find out which is more efficient between the use of pineapple peel extract and the use of povidone ioudium in the wound healing process.

Method: This type of research is an actual experiment with post-test control group design. The study was conducted on 18 Wistar white strain rats.

Result: There is a significant difference between wound care and povidone ioudium on the third, fifth and eighth-day observations with $p$ value 0.00 . Wound care using pineapple extract is more effective than treatment using povidone ioudium.

Conclusion: Further research is required by further refining the design and methodology of human research objects so it is safe and can be utilized as an alternative to herbal-based wound care.

Keywords: Wound care, incision injuries, Wistar white strain rats.

\section{INTRODUCTION}

The wound is a relatively common injury faced by the community. Injury can occur due to a deliberate process that is wound due to surgery or accidental due to accidental injuries accident and also burns. The existence of damage to the skin can reduce the ability of the first defense system in the body. According Smetzer (2003) skin is the first barrier for the human body. Loss of immune mechanism may affect the occurrence of infection. Nurses play a significant role in reducing the incidence of disease due to injury either through the role of collaboration or independent role. Wound care both surgical wounds and injuries due to injury often also combined with the use of antiseptic known as povidone iodine. Povidone iodine is often used for wound care, but systemic iodine absorption can cause toxic symptoms such as skin reactions, hypersensitivity, anxiety, depression, and myxoedema (Khan \& Naqvi, 2005). Therefore, the use of traditional medicinal plants in wound care to accelerate wound healing that safe for the body must be considered. Herbal remedies are easy to obtain because without a doctor's prescription society can have them. Besides, the price is relatively lower and has minimal side effects (Juckett, 2004).Some medicinal plants have been used as materials to accelerate the process of wound healing include pineapple fruit. Pineapple fruit is a fruit that has a very complex content, rich in minerals both macro and micro vitamins $\mathrm{C}$, carotenoids, fiber, anthocyanin, flavonoids organic substances, water and also vitamins and amino acids. In addition to the pineapple fruit has the effect of suppressing bacterial growth (Aichele et al., 2013). Research conducted by Dutta \& Bhattacharyya (2013) turns out pineapple fruit extract can also accelerate wound healing. Based on the phenomenon mentioned above, the researchers are interested to know more the effectiveness of which between usages of banana extract than the use of povidone iodium in incision wound healing. 


\section{MATERIALS AND METHODS}

The type of research is an actual experiment that provides treatment to objects that can control variables and state the cause and effect relationship.

The study design is a post test control group design. The treatment group was a group that performed wound care using pineapple extract while the control group performed wound care with povidone iodium. The sample size of each cluster was minimal using nine male Wistar white strain rats. Because there are two groups, then this study required a minimum of 18 mice.

\section{RESULT AND DISCUSSION}

The following table describes the wound length description in both groups after wound care.

Table1. Length of incision wound after treatment with pineapple fruit extract and povidone iodine

\begin{tabular}{|l|l|l|l|l|}
\hline \multicolumn{1}{|c|}{ Groups } & \multicolumn{1}{|c|}{$\mathbf{N}$} & $\begin{array}{c}\text { Average length of } \\
\text { wound on } \mathbf{3}^{\mathrm{rd}} \mathbf{d a y} \\
(\mathbf{X} \pm \mathbf{S D})\end{array}$ & $\begin{array}{c}\text { Average length of } \\
\text { wound on } \mathbf{5}^{\text {th }} \mathbf{d a y} \\
(\mathbf{X} \pm \mathbf{S D})\end{array}$ & $\begin{array}{c}\text { Average length of } \\
\text { wound on } \mathbf{8}^{\mathrm{th}} \\
\text { day } \\
(\mathbf{X} \pm \mathbf{S D})\end{array}$ \\
\hline $\begin{array}{l}\text { Wound treatment with } \\
\text { povidone iodium }\end{array}$ & 9 & $1.28 \pm 0.2$ & $1.03 \pm 0.2$ & $0.56 \pm 0.2$ \\
\hline $\begin{array}{l}\text { Wound treatment with } \\
\text { pineapple fruit extract }\end{array}$ & 9 & $1.32 \pm 0.1$ & $0.87 \pm 0.1$ & $0.37 \pm 0.18$ \\
\hline
\end{tabular}

Note: $(X+S D)$ in $\mathrm{cm}$

In the table above it appears that the average length of the wound on the third day in both groups showed treatment with povidone iodium is equal to $1.28+0.2$, and the length of the wound treated pineapple extract is equal to $1.32+0.1$.

Table2. Analysis of differences in wound length after treatment with povidone iodine

\begin{tabular}{|c|l|l|l|l|}
\hline Groups & \multicolumn{1}{|c|}{$\begin{array}{c}\text { Average length of } \\
\text { wound on } \mathbf{3}^{\text {rd }} \mathbf{d a y} \\
(\mathbf{X} \pm \mathbf{S D})\end{array}$} & $\begin{array}{c}\text { Average length of } \\
\text { wound on } \mathbf{5}^{\mathrm{th}} \mathbf{d a y} \\
(\mathbf{X} \pm \mathbf{S D})\end{array}$ & $\begin{array}{c}\text { Average length of } \\
\text { wound on } \mathbf{8}^{\text {th }} \\
(\mathbf{X} \pm \mathbf{S D})\end{array}$ & $\boldsymbol{P}-$ value \\
\hline \multirow{3}{*}{$\begin{array}{l}\text { Wound treatment with } \\
\text { povidone iodium }\end{array}$} & $1.28 \pm 0.2$ & $1.03 \pm 0.2$ & & 0.00 \\
\cline { 2 - 5 } & $1.28 \pm 0.2$ & & $0.56 \pm 0.2$ & 0.00 \\
\hline
\end{tabular}

Note : $(X \pm S D)$ in $\mathrm{cm}$

The difference in mean wound length in treatment with povidone iodine among the various observations was made by ANOVA post test using pairwise comparison as described in Table 2.

Table 3 shows that the difference between observations demonstrates the result of $\mathrm{p}$ - the value of 0.00 $(<0.05)$. It means that there is a difference in the average length of the wound between the observations of the third with the fifth day, the third with the eighth day and between the fifth and the eighth day.

The length of the wound treated with pineapple fruit extract was analyzed by ANOVA test with pairwise comparison method as seen in Table 3.

Table3.Analysis of differences in wound length after treatment with pineapple fruit extract

\begin{tabular}{|c|c|c|c|c|}
\hline Groups & $\begin{array}{c}\text { Average length of } \\
\text { wound on } 3^{\text {rd }} \text { day } \\
(X \pm S D)\end{array}$ & $\begin{array}{c}\text { Average length of } \\
\text { wound on } 5^{\text {th }} \text { day } \\
(X \pm S D)\end{array}$ & $\begin{array}{l}\text { Average length of } \\
\text { wound on } 8^{\text {th }} \text { day } \\
(X \pm S D)\end{array}$ & $P$ - value \\
\hline treatment & $1.28 \pm 0.2$ & $1.03 \pm 0.2$ & & 0.00 \\
\hline with pineapple fruit & $1.28 \pm 0.2$ & & $0.56 \pm 0.2$ & 0.00 \\
\hline extract & & $1.03 \pm 0.2$ & $0.56 \pm 0.2$ & 0.00 \\
\hline
\end{tabular}

Note : $(X+S D)$ in $\mathrm{cm}$

Table4. Analysis of differences in wound length in all three observations

\begin{tabular}{|l|l|l|l|l|}
\hline \multicolumn{1}{|c|}{ Groups } & $\begin{array}{c}\text { Average length of } \\
\text { wound on } \mathbf{3}^{\text {rd }} \text { day } \\
(\mathbf{X} \pm \mathbf{S D})\end{array}$ & $\begin{array}{c}\text { Average length of } \\
\text { wound on } \mathbf{5}^{\text {th }} \text { day } \\
(\mathbf{X} \pm \mathbf{S D})\end{array}$ & $\begin{array}{c}\text { Average length of } \\
\text { wound on } \mathbf{8}^{\mathrm{th}} \text { day } \\
(\mathbf{X} \pm \mathbf{S D})\end{array}$ & $\boldsymbol{P}-$ value \\
\hline $\begin{array}{l}\text { Wound treatment with } \\
\text { povidone iodium }\end{array}$ & $1.28 \pm 0.2$ & $1.03 \pm 0.2$ & $0.56 \pm 0.2$ & 0.00 \\
\hline $\begin{array}{l}\text { Wound treatment with } \\
\text { pineapple fruit extract }\end{array}$ & $1.32 \pm 0.1$ & $0.87 \pm 0.1$ & $0.37 \pm 0.18$ & 0.00 \\
\hline
\end{tabular}

Note : $(X \pm S D)$ in $\mathrm{cm}$ 
Table 4 shows that the difference between observations shows the result $p$ - value $<0.05$ which means there is a difference in the average length of the wound between the views of the third day and the fifth, the third day and the eighth as well as between the fifth and the eighth days. Differences in the length of wounds in both groups from observations on days three, five and eight is analyzed by using ANOVA test. The results of the analysis can be seen in Table 4.

The value of significance in all groups showed a significant difference from all observations because $\mathrm{p}$ value was equal to 0.00 . The difference in mean wound length between groups can be seen in Table5.

Table5. Analyzing differences in length of wounds between groups

\begin{tabular}{|l|l|l|l|}
\hline $\begin{array}{c}\text { Observation on wound } \\
\text { length }\end{array}$ & $\begin{array}{c}\text { Wound treatment with } \\
\text { povidone iodium } \\
(\mathbf{X} \pm \mathbf{S D})\end{array}$ & $\begin{array}{c}\text { Wound treatment with } \\
\text { pineapple fruit extract } \\
(\mathbf{X} \pm \text { SD) }\end{array}$ & p-value \\
\hline $3^{\text {rd }}$ day & $1.28 \pm 0.2$ & $1.23 \pm 0.1$ & 0.00 \\
\hline $5^{\text {th day }}$ & $1.03 \pm 0.2$ & $0.87 \pm 0.1$ & 0.00 \\
\hline $8^{\text {th }}$ day & $0.56 \pm 0.2$ & $0.37 \pm 0.18$ & 0.00 \\
\hline
\end{tabular}

As shown in the above table, quantitatively the average length of the wound in each group from several observations denote a difference as $\mathrm{p}$ value is $<0.05$.

Table 1 show that the average length of the wound in the care group with pineapple fruit extracts on observations of days five and eight indicates shorter than wound treatment group with povidone iodine. At each observation, the average length of the wound in both groups decreased. Thus it is concluded that in all methods of treatment occurs wound healing process. Table 2 shows that wound care with povidone iodine from observation of the third day to the eighth-day treatment statistically shows a significant decrease in wound length. This occurrence may be because povidone iodine is an antiseptic agent capable of inhibiting germ colonies, thus preventing infection process. According to Salma (2011), pure substances are capable of inhibiting the proliferation of bacteria which one of the antiseptic substances is povidone iodine. Healing wounds that are not infected or often called primary healing will indeed take place faster than the healing of infected wounds.

In the treatment using pineapple fruit extracts showed the shortening of wound length at each observation. Table 4 illustrates that wound care with pineapple fruit has significantly decreased the length of the wound from observation of the third day to the eighth-day treatment. In pineapple fruit contains active substance flavonoids, enzyme bromelain. Pineapple skin is a source of bromelain enzyme that has the effect of suppressing bacterial growth either bacteriostatic or bacteriocidal (Aichele et al., 2013). Enzyme bromelain can be used as an antibacterial effect. The way bromelain enzyme works is to lower the surface tension of bacteria by hydrolyzing the protein of the bromelain protein because it is proteolytic. The reduction of the surface tension of the bacterial cell wall causes the cell wall is not selective in passing solutes and other substances. These materials can change the physical and chemical properties of cell membranes and can block their normal function to inhibit and kill the bacteria (Aichele et al., 2013).

Other compounds contained in pineapple fruit that can be suspected to inhibit the growth of streptococcus are flavonoids. Flavonoids are phenol compounds that act as antibacterial and anti-fungal. The mechanism of action is by the denaturation of bacterial cell protein so that its characteristic is lost denaturation protein can damage cells by harvesting and cannot be repaired again. Flavonoids cause changes in organic components and transport of nutrients that cause toxic effects on bacteria. Enzyme bromelain in pineapple fruit other than as antibacterial, anti-inflammatory, and flavonoid, the formation of collagen pineapple fruit extract is also useful to accelerate wounds (Dutta \& Bhattacharyya 2013).

Comparison of wound length after wound treatment with povidone iodium with wound length after treatment with pineapple extract is presented in Table 3. It is clear that quantitatively it can be said that the use of wound care using pineapple extract shows a shorter wound quicker than the treatment wound with povidone iodine.

Wound healing consists of three phases: inflammatory phase (lag phase), tissue formation (proliferative phase), and tissue remodelling phase (Mansjoer, 2000). Each step 
of wound healing should normally be passed, so that wound healing is optimal. Povidone iodine is only antiseptic, so it does not affect directly to the tissue proliferation phase. Povidone iodine is an antiseptic capable of inhibiting germ colonies (Salma, 2011). In the absence of infection process, inflammation phase can occur optimally.

Pineapple fruit contains a substance capable of supporting the inflammatory phase and proliferation in the wound healing process. In pineapple fruit, there are flavonoids and enzyme bromelain. The most common use of bromelain is an anti-inflammatory agent (Dutta \& Bhattacharya, 2013). The more substances that can support the healing process of wound found on the fruit of pineapple wound treatment by using pineapple fruit extract is more effective than wound care with povidone ioudium.

\section{CONCLUSION}

The average length of the wound with treatment using pineapple extract from observation days to three, the fifth and eighth respectively are 1.32 $\mathrm{cm}, 0.87 \mathrm{~cm}$, and $0.37 \mathrm{~cm}$. The average length of the wound with treatment using povidone iodine from observation of the third, fifth and eighth days in the sequence was $1.28 \mathrm{~cm}, 1.03$ $\mathrm{cm}$, and $0.56 \mathrm{~cm}$. Wound care using pineapple extract is more efficient than using povidone ioudium. But further research is needed to refine the design and methodology with human research objects further so that pineapple extracts are safe to be used as alternatives to herbal-based wound care.

\section{REFERENCES}

[1]. Aichele K, Bubel M, Deubel G, Pohlemann T, Oberringer M (2013). Bromelain down-regulates myofibroblast differentiation in an in vitro wound healing assay. Pharmacol.386(10):85363

[2]. Dutta. S \& Bhattarchaya.,2013., Enzymatic, antimicrobial and toxicity studies of the aqueous extract of abuah nanas comosus crown leaf, $J$ Ethnopharmacol, 150(2):451-7

[3]. Juckett, G.,2004., Herbal Medicine. In: Craig C. R., Stitzel, R. E. ,editors: Modern Pharmacology with Clinical Applications. 6th ed. Philadelphia: Lippincott Williams \& Wilkins

[4]. Khan, M. N., Naqvi, A. H.( 2005). Antiseptics, Iodine, Povidone Iodine and Traumatic Wound Cleansing.

http://tvs.org.uk/sitedocument/Khan_16\%284\%2 9.pdf. 10 Desember 2011.

[5]. Salma.(2011) Mengenal Anti Septik. http://majalahkesehatan.com/mengenalantiseptik/ diaries 20 November 2015

[6]. Smeltzer, Suzanne C. (2003). Brunner \& Suddarth's Textbook of Medical Surgical Nursing,8th Edition, Agung Waluyo (penterjemah). Jakarta: EGC.

Citation: Syamsul Arif, Joni Siwanto, Putrono. Pineapples Extract as Replacement of Povidon Ioudium in Incision Wound Healing. ARC Journal of Surgery.2017;3(2):4-7.doi:dx.doi.org/10.20431/2455-572X.0302002.

Copyright: (C) 2017 Authors. This is an open-access article distributed under the terms of the Creative Commons Attribution License, which permits unrestricted use, distribution, and reproduction in any medium, provided the original author and source are credited. 